\title{
Analysis of Growth and Supply Responses of Selected Pulses in Bangladesh
}

\author{
M. A. Monayem Miah', M. A. Quddus², M. A. Matin' \\ M. N. Hasan ${ }^{3}$ and M. Aktar' \\ Agriculural Economics Division, BARI, Gazipur 1701, Bangladesh \\ ${ }^{2}$ Pulses Research Sub-station, BARl, Madaripar, Bangladesh \\ ${ }^{3}$ Department of Siatistics, BSMRAU, Saina, Gazipu 1706 Bangiadesh \\ Corresponding author and Enait nazmolh50s@yafoo.com
}

\begin{abstract}
The study estimated growth rates and supply response functions for various pulse crops in Bangladesh using time series data. Growth analysis revealed that the area indices for various pulse crops considering five years moving average showed an overall increasing trend over the period from 19821986 to 1992-1996. The production indices of different pulses also showed an increasing trend over the period from 1987-1991 to 2002-2006 with slight exception in the production of chickpea and blackgram during 2002-2006. The average growth rates of pulse area and production were 4.6 and 6.2 during pre-adoption period (1972-1991) and -5.6 and $-5.0 \%$ during post-adoption period (1992-2006), respectively. The yields of all pulse crops registered positive growth rates during 1972-2006 due to adoption of improved technologies. Significant structural changes occurred in the area and production of various pulses during post-adoption period due to policy effect and autonomous production. Again, positive structural changes also registered in the yield of mungbean and khesari and negative structural changes occurred for minor pulses during post-adoption period due to adoption of improved variety. Supply response functions fitted for various pulses revealed that lagged area and relative yield risk significantly influenced farmers to allocate land for lentil and chickpea cultivation.
\end{abstract}

Keyword: Growth analysis, pulses

\section{Introduction}

Pulses are important crops in Bangladesh. These crops are grown to 4,486 lakh hectares of land $(3.15 \%$ of the total cropped area) of the country (BBS, 2004). It plays an important role in sustaining the productivity of soils. They are generally grown without fertilizer since they can meet their nitrogen requirement by symbiotic fixation of atmospheric nitrogen in the soil (Islam, 1991; Senanayake et al., 1987; Zapata et al., 1987). It also supplies a substantial amount of nitrogen to the succeeding non-legume crops grown in rotation (Ahlawat ef al., 1981; Kurtz et ai, 1978).

Pulses have lost considerable amount of area across the country over the last two decades. A fall in the area under pulses has been observed in the country mainly due to the cultivation of HYV rice, wheat, tobacco, mustard and cotton (Miah, et al., 1991); high susceptibility enviromment; low responsiveness to irrigation and fertilizer; and few number of HYV pulses. Before the introduction of high-yielding varieties of cereals in the mid-sixties, the growth performance of almost all crops was more or less uniform. However, in the post-green revolution period, pulses received mostly marginal lands and residual inputs. With more and more cultivation of cereals like rice and wheat, the area under pulses it Bangladesh declined substantially during 1971-1980 to 1981-2006. The continuously declining trend in area and production of pulses in the recent years has 
become a serious concern of the planners and policy makers.

Supply response functions provide us with useful information on the extent of farmers' response to price and other economic factors. Most of the supply response studies on food grains have been conducted to cereals only. For pulses, however, a few studies are available to test the supply-price hypothesis. Studies conducted by Krishna (1963) and Sud and Kahlon (1969) show rather the weak rolc of prices in influencing the supply of pulses. In Pakistan, Dhindsa and Sharma (1997) studied the role of yield differentials, which represented production technology, risk and irrigation, influcnecd the farmer's acreage adjustment behaviour particularly with respect to various pulse crops. No attempt has been made earticr to study the stpply response behaviour of pulse crops in Bangladesh. Therefore, the present study attempts to analyse the growth bchaviour and factors influencing the supply of various pulse crops in Bangladesh.

\section{Objectives}

(1) To study the growth of area, production and yield of various putse crops in Bangladesh.

(2) To examine the acreage response of various factors determining decision regarding allocation of land among different pulse erops in Bangladesh.

(3) To suggest policy measures to increase the production of pulse crops in the country.

\section{Materials and Methods}

Time series data on area, production and yields of different pulse crops for 35 years from $1971 / 72$ to $2005 / 06$ were obtained from the website of the Minstry of Agriculture and different issues of the Statistical Yearbook of Bangladesh. The data on rainfall, gross irrigated area, and prices of different pulses were collected from unpubished records maintained by Ditectorate of Agricultural Marketing. The whole period (1972-2006) was divided into two major periods viz Period I (1972-1991) and period II (1992-2006) to compare the rate of changes occurred in the area, production and yield of different pulses and explore the causes of changes.

\subsection{Measuring the trend of change}

Five year moving average was used to estimate fluctuation and an index was prepared to compare the change in area, production and yield of different pulse crops considering 1972-1976 as base period. Index number was calculated as:

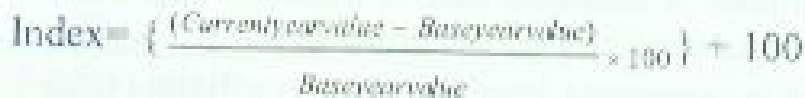

\subsection{Growth rate estimation}

The growth rates of area, production and yield of pulse crops were worked out by fitting a semilog function of the following type:

$$
y=e^{a+b i} \text { or } l_{n} y=a+b t
$$

Where, $y=$ Area (ha) or production (ton) or yield (tha), $\mathrm{t}=$ Time period (year)

\subsection{Test of structural stability}

It was assumed that the effect of policy reform might influence pulses production during postadoption period (1992-2006) since a number of improved pulse production technologies were developed and disseminated during these periods. Structural stability test was performed to verify the structural changes occurred in the area. production and productivity of different pulses between two periods of 1972-1991 and 19922006. In this study, from 1972 to 1991 was treated as period-1 (non-adoption period of improved pulse variety) and from 1992 to 2006 was treated as period-ll (adoption period of improved pulse variety). The following regression model was used for structural stability test.

$$
L n Y_{i}=\beta_{1}+\beta_{2} D_{i}+\beta_{3} X_{i}+\beta_{4} D_{i} X_{i}+U_{i}
$$

Where, $\mathrm{Yi}=$ Area (ha) or production (tha) or yicld (tha) of different pulses in $1^{\text {th }}$ year; $\mathrm{Di}=$ Period dummy ( 1 for $2^{\text {nd }}$ period, otherwise 0 ); $\mathrm{Xi}$ $=$ Time $(i=1,2,3 \ldots 35) ; \beta_{1}$ is general intercept; $\beta_{2}$ is differential intercept; and $\beta_{4}$ is differential slope coefficient. $\beta_{2}$ indicates the significant change occurred in the $2^{\text {st }}$ period. On the other hand, $\beta_{4}$ indicates how much the slope coefficient of $2^{\text {id }}$ period differs from the slope coefficient of 
$1^{\text {st }}$ period. It means that the rate of change occurred in period II over time. When Di $=1$, then $\ln Y_{i}=\left(\beta_{1}+\beta_{2}\right)-\left(\beta_{3}+\beta_{4}\right) X i=\gamma_{1}+\gamma_{2} X i$; when Di 0 , then $\ln Y i=\beta_{1}-\beta_{3} X i$. The null bypothesis of the structural stability test is Ho: $\gamma_{1}=\beta_{1}$ and $\gamma_{2}=$ $\beta_{3}$. If the $1^{\text {st }}$ ntIl hypothesis is accepted then it indicates that there is no change occurred in the $2^{\text {tit }}$ period, which is originated from the intercept (due to autonomous production). If the $2^{\text {pd }}$ null hypothesis is accepted then it indicates that there is no structural change occurred in the $2^{\text {nd }}$ period, which is originated from the slope coefficient (due to adoption effect).

\subsection{Estimation of supply response}

Nerlovian partial adjustment lag model (Nerlove, 1956) was used for estimating supply response for various pulse crops in Bangladesh. The model implies that the change in current area is in proportion to the difference between the longrun equilibrium area and an actual area in the previous year. The double-log (natural) form of the Nerlovian partial model was employed in view of its suitability to the data. Hence, we get the following basic equation:

$\operatorname{Ln} A_{t}=b_{9}+b_{1} \operatorname{LnRP}_{t a}+b_{2} L_{n R Y} Y_{t}+b_{3} \operatorname{LnCV}_{R P}$ $+b_{4} \operatorname{LnCV}_{R Y}+b_{5} \operatorname{Ln} A_{t-1}+U_{t}$

Where, " $t$ " always refers to the $t$-th production period.

$A_{1}=$ The actual area (ha) planted under the crop coneerned, which is used as a depended variable.

$A_{1-1}=$ One year'lagged area (ha) under the erop concerned

$\mathrm{RP}_{1-1}=$ Relative price, i.e., ratio of the price of the crop concerned to the price the competitive crop.

$R Y_{1-1}=$ Relative yield, i.e., ratio of the yield of the crop concerned to yield of the competitive crop.

$\mathrm{CV}_{\mathrm{RP}}$ and $\mathrm{CV}_{\mathrm{RY}}=$ The coef icients of variation of the preceding one years' relative price and relative yield respectively.

$1_{1}=$ Gross irrigated area (ha) under all selected crops.

$\mathrm{L}_{\mathrm{i}}=$ Error term

\section{Results and Discussion}

\subsection{Trend of area and production of pulses}

An index approach considering five years moving average was applied to show the trend of area and production of different pulses in Bangladesh. The area indices constructed for different pulses showed an overall increasing trend over the period from 1982-1986 to 19921996 (Table 1). The area under chickpea, lentil, blackgram and other minor pulses (t.e. orhor. motor, etc) drastically decreased over the period from 1997-2001 to 2002-2006 compared to base year of 1972-1976. The reasons for decreasing pulse area were: i) most lentil and blackgram areas were replaced by boro rice, wheat, tobacco, mustard and cotton due to their high yield potential and better economic returns (Miah et di., 1991); ii) pulse crops are highly susceptible to environmental stresses; iii) the economic returns of these crops were not satisfactory to the farmers compared with other competing crops; and iv) low response to irrigation and fertilizer use. The area indices for mungbean and khesari represented an impressive increasing trend over the period from 1982-1986 to 2002-2006 which might be due to introduction of its improved varieties that started from 1992 (Table 1). However, the area under all types of pulses decreased during 2002-2006 compared to its base period as well as its previous periods.

The indices prepared for the production of different pulses showed an increasing trend over the period from 1987-1991 to 2002-2006 with slight exception in the production of chickpea and blackgram during 2002-2006. In this period, the production of chickpea and blackgram decreased to a greater extent due to decrease in area. On the other hand, the index of lentil production showed an increasing trend compared to its area which might be duc to higher productivity. The trend of other minor pulses production was found to be satisfactory (Table 1). However, the production of all types of pulses decreased during 2002-2006 compared to its base period as well as its previous periods. 
Table 1. Index of area and production of pulses in Bangladesh.

\begin{tabular}{|c|c|c|c|c|c|c|c|}
\hline Vear & Chickpeil & Mungbean & Lentil & Khesari & Blackgram & Other pulses & All Pulses \\
\hline \multicolumn{8}{|c|}{ Area Index } \\
\hline $1972-1976$ & 100 & 100 & 100 & 100 & 100 & 100 & 100 \\
\hline $1977-1981$ & 96 & 113 & 44 & 115 & 98 & 84 & 77 \\
\hline $1982-1986$ & 146 & 296 & 91 & 207 & 122 & 101 & 132 \\
\hline $1987-1991$ & 171 & 412 & 114 & 280 & 135 & 143 & 169 \\
\hline $1992-1996$ & 140 & 383 & 111 & 292 & 132 & 129 & 163 \\
\hline $1997-2001$ & 97 & 385 & 102 & 252 & 97 & 84 & 137 \\
\hline $2002-2006$ & 24 & 254 & 81 & 192 & 48 & 56 & 94 \\
\hline \multicolumn{8}{|c|}{ Production Index } \\
\hline $1972-1976$ & 100 & 100 & 100 & 100 & 100 & 100 & 100 \\
\hline $1977-1981$ & 94 & 97 & 108 & 104 & 88 & 138 & 102 \\
\hline $1982-1986$ & 150 & 257 & 253 & 203 & 108 & 115 & 182 \\
\hline $1987-199 \mid$ & 169 & 348 & 340 & 264 & 124 & 254 & 238 \\
\hline $1992-1996$ & 140 & 342 & 359 & 285 & 128 & 223 & 241 \\
\hline$|997-200|$ & 96 & 375 & 329 & 264 & 91 & 213 & 214 \\
\hline $2002-2006$ & 24 & 272 & 258 & 212 & 45 & 78 & 147 \\
\hline
\end{tabular}

Source: Ministry of Agriculture (www. moa.gov bd)

\subsection{Rase of change in srea, production and productivity of pulses}

The area und production of mungbean, lentil and khesari registered higher growth rates, while negative growth rates were found in the cases of blackgram, chickpea and other minor pulses over the 35 years (1972-2006). The overall growth rate of pulse production was higher than the growth rate of pulse area (Table 2). The table further shows that the area and production of alt types of pulses registered positive growth rates during pre-adoption period (1972-1991), but showed negative growth rates during postadoption period (1992-2006). The average growth raes of pulse area and production were 4.6 and $6.2 \%$ during pre-adoption period and 5.6 and $-5.0 \%$ during post-adoption period respectively. In spite of adoption of improved technolog of pulses, the area and production registered negative growth rates during postadoption period. The reasons behind this negative growth were that the pulse farmers were compelled to reduce their pulse area and switch on to other crops, as its cultivation was less profitable and susceptible to environment compared to other competing crops e.g. vegetables, Boro rice.
The overall productivity growth of all types of pulses increased during 1972-2006 die to adoption of improved technologies. This fact can also be seen in the post-adoption period as the productivity growth of major pulses excep: blackgram and other minor pulses increased although the growth of pulses area decreased during this period (Table 2).

\section{3. Structural stability test}

Table 3 depicts that all the differential intercepts $\left(\beta_{2}\right)$ of different pulses area and production are highly significant and all the $1^{\text {"1 }}$ null hypotheses are rejected, which indicates that there are significant differences in the area and production of different pulses between 'pre adoption' period (1972-1991) and 'post adoption' period (19922006). On the other hand, the differential slope coefficient $\left(\beta_{4}\right)$ indicates the mature of changes occurred in the area and production of different palses over time. All the $\beta_{4}$ are negatively significant at $1 \%$ level and all the $2^{\text {ne }}$ null hypotheses are rejected which indicate that there are structural changes in the area and production of different pulses during post adoption period due to policy effect and autonomous production as well. 
Table 2. Rate of change in area, production and yield of pulses during major improved pulses adoption period (1972-2006) in Bangladesh.

\begin{tabular}{|c|c|c|c|c|c|c|c|}
\hline \multirow[t]{2}{*}{ Year } & Yungbean & Lentil & Blackgram & Chickpea & Khesari & $\begin{array}{l}\text { Other } \\
\text { pulses }\end{array}$ & $\begin{array}{c}\text { All } \\
\text { pulses }\end{array}$ \\
\hline & \multicolumn{7}{|c|}{ Area } \\
\hline $1972-1991$ & 10.0 & 5,2 & 2.2 & 3.9 & 7.1 & 2.4 & 4.6 \\
\hline $1992-2006$ & -4.8 & -3.2 & -10.0 & -17.8 & -4.4 & -8.5 & -5.6 \\
\hline $1972-2006$ & 4.0 & 2.2 & -1.6 & -3.5 & 2.8 & -1.1 & 1.1 \\
\hline \multirow[t]{2}{*}{ "/. Change* } & +32.3 & +11.2 & -18.6 & $-32,3$ & +28.4 & -16.2 & +9.2 \\
\hline & \multicolumn{7}{|c|}{ Production } \\
\hline $1972-1991$ & 90 & 8.7 & 1.7 & 3.9 & 6.9 & 5.2 & 6.2 \\
\hline $1992-2006$ & -2.9 & 3.2 & -10.3 & -17.6 & -3.1 & -15.0 & -5.0 \\
\hline $1972-2006$ & 4.4 & 4.0 & -1.6 & -3.4 & 3.2 & -0.4 & 2.1 \\
\hline \multirow[t]{2}{*}{ \% Change* } & +39.2 & -36.5 & $-16,0$ & -32.4 & +33.9 & 11.3 & 22.5 \\
\hline & \multicolumn{7}{|c|}{ Yield } \\
\hline $1972-1991$ & -1.0 & 3.5 & -0.6 & -0.1 & -0.2 & 2.8 & 1.5 \\
\hline $1992-2006$ & 1.9 & 0.1 & -0.3 & 0.2 & 1.3 & -6.5 & 0.6 \\
\hline $1972-2006$ & 0.4 & 1.8 & 0.0 & 0.1 & 0.4 & 0.7 & 1.0 \\
\hline$\%$ Change $*$ & -9.8 & +18.3 & +2.4 & +0.96 & +8.5 & -25.9 & -13.3 \\
\hline
\end{tabular}

\$ " change in the mean areaproductionyield of period 1992-2006 over 1972-1991.

Table 3 further reveals that the differential intercepts $\left(\beta_{2}\right)$ of mungbean, khesari and other pulses yield are highly and all the $1^{\text {st }}$ null hypotheses of these pulses vield are rejected implying that there are significant differences between two periods, which is originated from the intercept (due to autonomous production). Again, the differential slope coefficients $\left(\beta_{4}\right)$ of mungbean and khesari yicld are positively significant at $1 \%$ level which indicate that there are positive structural changes in the yield of these two pulses during post-adoption period due to adoption of improved varicties. On the other hand, negative structural changes have been occurred in the yields of other minor pulses. The differential intercepts of the yields of Ientil. blackgram, and chickpea are not significant and the corresponding null hypotheses are accepted implying that there are no difterences in the yields of these pulses between two periods. Again, the differential slope coefficients $\left(\beta_{4}\right)$ of these pulse yields are also insignificant and the corresponding null hypotheses are rejected mdicating that structural chanes occurred in the yields of those pulses to some extent, but those changes are not significant at desired level confidence.

\section{4. Supply Response Behaviour of Pulses}

An attempt was made to study the supply response of various pulse crops namely lentil, chickpea, mungbean and blackgram in Bangladesh during the period 1979780 to 2004/05.The competing crops selected in respect of each of the crops studied were Boro rice, wheat and mustard. Different supply response functions fitted for various pulse crops showed that Boro rice competed with lentil and chickpea, while mustard competed with mungbean and blackgram.

It was assumed that the area under various pulses is likely to be influenced by different variables such as lagged area, lagged relative price, lagged relative yield, relative price risk, relative yield risk and gross irrigated area. Price is one of the tmportant variables that influence farmers to allocate area for crop production. It is evident that farmers produce different crops mostly depending on previous year's harvest price. 
Table 3. Test of structural stability in area, production and yield between "pre-adoption (1972. $1991)^{\prime}$ and 'post-adoption (1992-2006)' of majot improved putses in Bangladesh.

\begin{tabular}{|c|c|c|c|c|c|c|c|c|c|}
\hline Pulses & $\begin{array}{c}\beta \\
\text { (t-value) }\end{array}$ & $\begin{array}{c}\beta_{2} \\
\text { (1-value) }\end{array}$ & $\begin{array}{c}\text { б3 } \\
\text { (t-พa|ue) }\end{array}$ & $\begin{array}{c}\beta_{4} \\
\text { (t-value) }\end{array}$ & $\begin{array}{c}\mathrm{A}^{\mathrm{C}} \\
\text { (F. } \\
\text { value) }\end{array}$ & $\begin{array}{c}y \\
\left\{3_{1}+\right. \\
\left.\beta_{2}\right)\end{array}$ & $\begin{array}{c}\gamma_{2} \\
\langle\beta t+\beta t\end{array}$ & $\begin{array}{r}\mathrm{H}_{2} \\
\gamma, \beta\end{array}$ & $\begin{array}{l}H_{3} \\
Y_{2} \beta_{3}\end{array}$ \\
\hline & \multicolumn{9}{|c|}{ Area } \\
\hline Mungbcan & $\begin{array}{l}9.1066^{\circ} \\
(62.15)\end{array}$ & $\begin{array}{l}3.004^{\circ} \\
(5.42)\end{array}$ & $\begin{array}{l}0.1057^{\circ} \\
(2.23)\end{array}$ & $\begin{array}{l}-0.14 \mathrm{G})^{\prime} \\
(-3.53)\end{array}$ & $\begin{array}{l}0.771 \\
(34.7 \%)\end{array}$ & 12.1103 & -0.0453 & Hejected & Fejected \\
\hline Lenti & $\begin{array}{l}11.211^{\circ} \\
(52.21)\end{array}$ & $\begin{array}{l}1.7884^{*} \\
(2.20)\end{array}$ & $\begin{array}{l}0.0523^{\circ} \\
(2.91)\end{array}$ & $\begin{array}{l}-0,084^{\circ} \\
(-2.56)\end{array}$ & $\begin{array}{l}0.319 \\
(4.85)\end{array}$ & 12.9997 & -0.0320 & Bejected & Pejected \\
\hline B ackgrem & $\begin{array}{l}10.710^{\circ} \\
(122.05)\end{array}$ & $\begin{array}{l}2.7434^{\circ} \\
(8.34)\end{array}$ & $\begin{array}{l}0.0224^{\circ} \\
\text { (3.C8) }\end{array}$ & $\begin{array}{l}-0.1224^{\circ} \\
(-9.17)\end{array}$ & $\begin{array}{l}0.779^{\circ} \\
\left(36.62^{\circ}\right)\end{array}$ & 13.4537 & -0.1000 & Rejected & Rejected \\
\hline Chickpea & $\begin{array}{l}10.783^{\circ} \\
(70.52)\end{array}$ & $\begin{array}{l}4.7229^{\circ} \\
(8.17)\end{array}$ & $\begin{array}{l}0.0393^{*} \\
(3.06)\end{array}$ & $\begin{array}{l}-0.2174^{+} \\
(-9.27)\end{array}$ & $\begin{array}{l}0.804 \\
\left(62.49^{\circ}\right)\end{array}$ & $15.50 \mathrm{~s} 3$ & -0.1781 & Hejected & Rejec:ed \\
\hline Khesan & $\begin{array}{l}11.037^{\prime} \\
(126.41)\end{array}$ & $\begin{array}{l}2.4034^{\circ} \\
(7.28)\end{array}$ & $\begin{array}{l}0.0713^{*} \\
(9.78)\end{array}$ & $\begin{array}{l}-0.1150^{\prime} \\
(-5.59)\end{array}$ & $\begin{array}{l}0.833 \\
(51.82 *)\end{array}$ & 13.4497 & -0.0. & Rejected & Pejected \\
\hline Other pulses & $\begin{array}{l}10.333^{\circ} \\
(102.87)\end{array}$ & $\begin{array}{l}2.4217^{\circ} \\
(6.35)\end{array}$ & $\begin{array}{l}0.0241^{*} \\
(2.28)\end{array}$ & $\begin{array}{l}-0.1051^{*} \\
(-7.08)\end{array}$ & $\begin{array}{l}0.658 \\
\left(19.87^{*}\right)\end{array}$ & 12.7550 & -0.0850 & Rejected & Rejected \\
\hline \multirow[t]{2}{*}{ Al pulses } & $\begin{array}{l}12.574^{\prime} \\
(96.43)\end{array}$ & $\begin{array}{l}2.2173^{\circ} \\
(4.50)\end{array}$ & $\begin{array}{l}0.0454^{\circ} \\
(4.27)\end{array}$ & $\begin{array}{l}-0.1025^{*} \\
\langle-5.73\}\end{array}$ & $\begin{array}{l}0.509 \\
\left(10.71^{\circ}\right)\end{array}$ & 14.7913 & .0 .0561 & Re,ected & Hejected \\
\hline & \multicolumn{9}{|c|}{ Poducton } \\
\hline Mur & $\begin{array}{l}8.6560^{\circ} \\
(53.05)\end{array}$ & $\begin{array}{l}2.4560^{\circ} \\
(3.98)\end{array}$ & $\begin{array}{l}0.0903^{*} \\
(6.61)\end{array}$ & $\begin{array}{l}-0.119 \% \\
\{-4.76)\end{array}$ & $\begin{array}{l}0.719 \\
\left(26 \angle 4^{*}\right)\end{array}$ & 11.1120 & -0.0291 & ad & Bejo \\
\hline Lentil & $\begin{array}{l}10.3310 \\
(85.72)\end{array}$ & $\begin{array}{l}2.4220^{\circ} \\
(5.39)\end{array}$ & $\begin{array}{l}0.0873^{\prime} \\
(8.78)\end{array}$ & $\begin{array}{l}-0.1189^{\prime} \\
\langle-6.51\rangle\end{array}$ & $\begin{array}{l}0.839 \\
(43.72 \%)\end{array}$ & $12,75 \%$ & .0 .0316 & Rejected & Hejected \\
\hline Blackgram & $\begin{array}{l}10.4 \div 83 \\
(1+1.28)\end{array}$ & $\begin{array}{l}2.8100^{\circ} \\
(7.92)\end{array}$ & $\begin{array}{l}0.0169^{\circ} \\
(2.17)\end{array}$ & $\begin{array}{l}-0.265^{\circ} \\
\{-3.37\}\end{array}$ & $\begin{array}{l}0.750 \\
(31.05)\end{array}$ & 13.2583 & -0.1036 & Rejected & Hejected \\
\hline Chickpea & $\begin{array}{l}10.4519 \\
(65.53)\end{array}$ & $\begin{array}{l}4.6717 \\
(7.50)\end{array}$ & $\begin{array}{l}0.0358^{\circ} \\
(2.97)\end{array}$ & $\begin{array}{l}-0.2175^{\circ} \\
\{8.95\}\end{array}$ & $\begin{array}{l}0.792 \\
\left(39.44^{*}\right)\end{array}$ & 15.1330 & -0.1790 & Rejected & Pejected \\
\hline Khesan & $\begin{array}{l}10.7529 \\
(108.96)\end{array}$ & $\begin{array}{l}2.1+14^{\circ} \\
(5.65)\end{array}$ & $\begin{array}{l}0.0685^{\prime} \\
(8.33)\end{array}$ & $\begin{array}{l}-0.0998^{*} \\
(-6.59)\end{array}$ & $\begin{array}{l}0.503 \\
(42.11 \%)\end{array}$ & 12.8643 & -0.0312 & Rejected & Bejected \\
\hline Other pulses & $\begin{array}{l}9.3516^{\circ} \\
(47.62)\end{array}$ & $\begin{array}{l}4.7058^{\circ} \\
(6.34)\end{array}$ & $\begin{array}{l}0.0518^{*} \\
(3.16)\end{array}$ & $\begin{array}{l}-0.2319^{\prime} \\
\{6.71\}\end{array}$ & $\begin{array}{l}0.594 \\
\left(15.13^{\circ}\right)\end{array}$ & 14.0554 & -0.1501 & Rejectod & Rejected \\
\hline \multirow[t]{2}{*}{ All pulses } & $\begin{array}{l}11.9856 \\
(12509)\end{array}$ & $\begin{array}{l}2.3674^{\circ} \\
(6.54)\end{array}$ & $\begin{array}{l}0.0617^{*} \\
(7.71)\end{array}$ & $\begin{array}{l}-0,1116^{*} \\
\langle-7,59\rangle\end{array}$ & $\begin{array}{l}0.758 \\
\left(32.28^{\circ}\right)\end{array}$ & 14.3580 & -0.0499 & Rejected & Aejected \\
\hline & \multicolumn{9}{|l|}{ Yielc } \\
\hline Murgbein & $\begin{array}{l}-0.4497^{*} \\
(-13.39)\end{array}$ & $\begin{array}{l}-0.5316^{\circ} \\
(-4.19)\end{array}$ & $\begin{array}{l}-0.0105^{\circ} \\
(-3.73)\end{array}$ & $\begin{array}{l}0.0293^{\circ} \\
\langle 5.70\rangle\end{array}$ & $\begin{array}{l}0.625 \\
\left\{17.23^{4}\right)\end{array}$ & 0.9813 & 0.0188 & Rejected & Acoepted \\
\hline Lent: & $\begin{array}{l}-6.8806^{\circ} \\
(-4.95)\end{array}$ & $\begin{array}{l}0.6287 \\
(0.54)\end{array}$ & $\begin{array}{l}0.0351^{*} \\
(2.36)\end{array}$ & $\begin{array}{l}0.0346 \\
\{-1.27\}\end{array}$ & $\begin{array}{l}-0.0345 \\
\left(-1,27^{*}\right)\end{array}$ & .0 .2519 & 0.0005 & Ascepted & Rejected \\
\hline Blackgram & $\begin{array}{l}-0.2623^{\circ} \\
(-11.65)\end{array}$ & $\begin{array}{l}0.0616 \\
(0.72)\end{array}$ & $\begin{array}{l}-0.0055^{\circ} \\
(-2.93)\end{array}$ & $\begin{array}{l}0.0022 \\
(0.62)\end{array}$ & $\begin{array}{l}0.284 \\
\left(4.10^{* 1}\right)\end{array}$ & -0.2007 & -0.0033 & Aocepted & Hejected \\
\hline Chickpea & $\begin{array}{l}-0.3202^{\circ} \\
(-12.63)\end{array}$ & $\begin{array}{l}-0.0465 \\
(-0.49)\end{array}$ & $\begin{array}{l}-0.0006 \\
(-0.27)\end{array}$ & $\begin{array}{l}0.0024 \\
\langle 0,62\}\end{array}$ & $\begin{array}{l}0.025 \\
(0.26)\end{array}$ & -0.3567 & 0.0018 & Accepted & Rejected \\
\hline Khesan & $\begin{array}{l}-0.2885^{\circ} \\
(-12.82)\end{array}$ & $\begin{array}{l}-0.3006^{\circ} \\
(-3.53)\end{array}$ & $\begin{array}{l}-0.0022 \\
(-1.20)\end{array}$ & $\begin{array}{l}0.0153^{\circ} \\
(4.44)\end{array}$ & $\begin{array}{l}0.620 \\
\{16.87 \%\end{array}$ & -0.5891 & 0.0131 & Rejected & Accepted \\
\hline Otherpilses & $\begin{array}{l}-0.9836^{\circ} \\
(-4.42)\end{array}$ & $\begin{array}{l}2.2859^{\circ} \\
(2.73)\end{array}$ & $\begin{array}{l}0.0275 \\
(1,46)\end{array}$ & $\begin{array}{l}-0.0928^{\circ} \\
(-2.73)\end{array}$ & $\begin{array}{l}0.216 \\
\left(2.85^{* \prime \prime}\right)\end{array}$ & 1.3053 & -0.0652 & Rejected & Aejected \\
\hline All pulses & $\begin{array}{l}-0.5951^{\circ} \\
(-6.87)\end{array}$ & $\begin{array}{l}0.1487 \\
(0.46)\end{array}$ & $\begin{array}{l}0.0152^{*} \\
(2.13)\end{array}$ & $\begin{array}{l}-0.0089 \\
(-0.68)\end{array}$ & $\begin{array}{l}0.273 \\
\left(3.89^{\prime \prime}\right)\end{array}$ & -0.4414 & 0.0063 & ed & $\mathrm{Hej}$ \\
\hline
\end{tabular}

"w' and '"*' indicate significant at $1 \%$ and $5 \%$ levels respectively. 
Table 4. Estimates of area response functions of pulses in Bangladesh, 1979-1980 to 2004-2005.

\begin{tabular}{|c|c|c|c|c|}
\hline Variables & Lentil & Chickpea & Mungbean & Blackgram \\
\hline Constant & 1.6012 & 7.2734 & 10.5621 & 5.2495 \\
\hline Lagged area $\left(A_{t-1}\right)$ & $\begin{array}{l}0.4289^{* *} \\
(2.05)\end{array}$ & $\begin{array}{l}0.6736^{* * 8} \\
(5.29)\end{array}$ & $\begin{array}{l}0.8239^{*}: * * \\
(4.87)\end{array}$ & $\begin{array}{l}0.7552^{* * * *} \\
(5.58)\end{array}$ \\
\hline \multirow{2}{*}{ Lagged relative price $\left(\mathrm{RP}_{\mathrm{t}-1}\right)$} & -0.4250 & -0.0653 & 0.3585 & -0.0599 \\
\hline & $(-1.35)$ & $(-0.15)$ & $(1.04)$ & $(-0,16)$ \\
\hline \multirow{2}{*}{ Lagged relative yield ( $\left.R Y_{t-1}\right)$} & -3.9140 & 1.3307 & 1.5022 & $1.3917 *$ \\
\hline & $(-2.41)$ & $(0.91)$ & $(1.67)$ & $(1.85)$ \\
\hline \multirow{2}{*}{ Relative price risk (CV $\mathrm{RP}$ ) } & -0.0391 & $-0.1241^{\circ}$ & 0.0266 & -0.0526 \\
\hline & $(-0.96)$ & $(-1.97)$ & $(0.55)$ & $(-0.71)$ \\
\hline \multirow{2}{*}{ Relative yield risk (CV $\left.V_{Y R}\right)$} & $5.1143^{\text {*⿻一 }}$ & 0.1789 ** & -0.0773 & -0.0029 \\
\hline & $(3.09)$ & $(2.26)$ & $(-1.06)$ & $(-0.07)$ \\
\hline \multirow{2}{*}{ Irrigated area $\left(\mathrm{I}_{1}\right)$} & 0.4900 & -0.1267 & $-0.5656^{*}$ & -0.1721 \\
\hline & $(1.54)$ & $(-0.27)$ & $(-0.1 .99)$ & $(-0.75)$ \\
\hline $\mathrm{R}^{1}$ & 0.742 & 0.899 & 0.701 & 0.804 \\
\hline F-value $(6,18)$ & $8.605^{* * *}$ & $26.621 * * *$ & $7.042^{*: * *}$ & $12.273^{* * *}$ \\
\hline & 25 & 25 & 25 & 25 \\
\hline D-W test statistic & 1.843 & 2.415 & 1.296 & 1.870 \\
\hline
\end{tabular}

Note: (i) 'm**+*' and '*' represent $1 \%, 5 \%$ and $10 \%$ level of significant.

(ii) Figures in the parentheses are t-value.

Therefore, the harvest prices of crops were taken into consideration in this study, because wholesale and retail prices may not sometime reflect the actual price received by the farmers. On the other hand, the risks due to variations in yield and price are expected to act as deterrent factors on acreage under various pulse crops during a particular year. Therefore, only the price and yield risk or the coefficient of variations of prices and yield of different pulses for the preceding two years (CV) were used in this study as risk variables. This might be a sufficient way to incorporate risk particularly in the annual time series aggregate model (Sidhu and Sidhu, 1988). The study also hypothesized that an increase in gross irrigated area in Bangladesh would cause a reduction in the area under various pulse crops. This is due to the fact that old varieties of most of these crops give lower yicld on irrigated land, whereas new varieties of Boro rice and wheat give very high yjeld on rrigated land. The estimated elasticity coefficients of different supply response variables are shown in Table 4 and discussed below.

\section{4. 1. Lagged area}

The elasticity estimates of lagged area were found to be positive and significant at 1\% level for all selected pulse crops. It implies that allocation of area under pulse crops in the preceding year had significant influence on current year's allocation. The lagged area influence was found higher on the allocation of land for mungbean production followed by blackgram, chickpea and lentil. The magnitude of coefficient for munglean is close to 1 , indieating that the farmers had considerably high adjustment response (Tabie 4).

\section{4. 2. Lagged relative price}

The results of the regression analysis presented in Table 4 show that the relative prices of lentil and chickpea vis-a-vis Boro rice, and blackgram in comparison with mustard showed insignificant negative impact on area under lentil, chickpea 
and blackgram in Bangladesh. The insignificant impact of relative price variable would show that the farmers did not consider the changes in relative prices of lentil, chickpea and blackgram, while allocating area under these crops. On the other hand, insignificant positive impact was found in the case of mungbean but this impact was not significant.

\section{4, 3. Lagged relative yield}

The lagged relative yield of blackgram with respect to competing crop mustard has registered positive and significant impact on acreage allocation under blackgram cultivation. The short-run clasticity of blackgram with respect to relative yicld variable was 1.39 for the country. The lagged relative yield of lentil turned out to be insignificant and negative which implied that the lentil farmer in the country did not consider the lagged relative yield of lentil vis-à-vis Boro rice during allocation of land for Ientil cultivation It was fact that the area and production of lentil drastically decreased over the period from 1997-2001 to 2002-2006 compared to base period (1972-1976) with slightly increased yield in that period.

\section{4. 4. Risk factors}

Of the various pulse crops considered in the analysis, risk arising due to variations in relative price and relative yield. The elasticity coefficients of lentil, chickpea and blackgram were negative and it was positive for mungbean. Price risk variable with negative sign implied furmers' risk aversion response to price fluctuation which means that pulse farmers appeared to be risk lovers by putting less area under the crop. On the other hand, farmers did not consider relative price risk during allocation of mungbean cultivation which might be due to its all season production nature.

The elasticities of yield risk variable were found to be posizive and significant at $5 \%$ level for Ientil and chickpea which indicate that the farmers did not consider relative yield risk in cultivating the aforesaid pulses. They cultivate these two pulse crops mostly for their household need. Thus, the lentil and chickpea farmers in the country exhibited yield risk aversion attitude as the yield risk variable came out with negative sign. On the other hand, the yield risk variable was found insignificant and with negative sign for mungbean and blackgram production indicating that the cultivation of these two crops negatively influenced with yield risk.

\section{4. 5. Irrigated Area}

Increase in gross irrigated area in the country has registered in a fall in the area under chickpea, blackgram and lentil. The coefficients of irrigated area variable in chickpea, mungbean and blackgram have emerged negative sign implying that irrigation had the most adverse impact on the cultivation of the above pulse crops in the country with short-run elasticity of $0.126,-0.565$ and -0.172 , respectively. Besides, the elasticity coefficient of irrigated variable for mungbean was negatively significant at $10 \%$ level. This means that one percent increase in irrigated area would decrease the mungbean area by $0.265 \%$ keeping other variables constant, In the case of lentil, the coefficient $(0.490)$ was positive and insignificant indicating that farmers considered irrigation factor during allocation of land for lentil cultivation.

\section{Conclusions and Recommendations}

The study has analyzed the growth of area, production and yield of various pulse crops and estimated the supply response functions for various pulse crops in Bangladesh. Area indices show that the area under chickpea, lentil, blackgram and other minor pulses drastically decreased over the period from 1997-2001 to 2002-2006 compared to base period (1972. 1976). Again, the area indices for mungbean and khesari represented an impressive increasing trend over the period from 1982-1986 to 20022006 which might be due to introduction of its improved varieties. The production indices of different pulses showed an increasing trend over 
the period from 1987-1991 to 2002-2006 with slight exception in the production of chickpea and blackgram during 2002-2006. The index of lentil production showed an increasing trend compared to its area which might be due to higher productivity.

The area and production of all types of pulses registered positive growh rates during preadoption period (1972-1991) but showed negative growth rates during post-adoption period (1992-2006). The overall productivity growth of all types of pulses increased during 1972-2006 due to adoption of improved technologies. Significant structural changes have occurred in the area and production of different pulses during post adoption period due to policy effect and autonomous production as well. Again, positive structural changes have also been registered in the yield of mungbean and khesari and negative structural changes were found in the yield of minor pulses during post-adoption period due to adoption of improved varicty.

Supply response functions fitted for various pulses revealed that lagged area and relative yield risk sigmificantly influenced farmers to allocate land for lentil and chickpea cultivation. They do not consider relative yield risk in cultivating these two crops. The lagged relative yield of blackgram with respect to mustard has registered positive and significant impact on acreage allocation under blackgram cultivation. Farmer shows risk aversion attitude toward relative price risk variable by putting less area under lentil, chickpea and blackgram. Irrigated area variable shows the most adverse impact on the cultivation of chickpea, mungbean and blackgram.

It is recommended that for the dissemination of BARI released HYV pulse varieties to the farmers, existing on-farm research trial, pilot production programme, and block farming of improved pulse crops should be strengthened and extended these programme to other new areas.
Regular training programme on the production technology of various pulse crops should be organized for farmers, extension workers and private seed companies for quick dissemination of improved pulse varieties.

\section{References}

Ahlawat, I.P.S., Singh. A., Saraf, C.S., 1981. Effect of winter legumes on nitrogen economy and productivity of succeeding cereals. Experimental Agriculuare 17, 5762.

BBS. 2004. Bangladesh Bureau of Statistics. Yearbook of Agricaltural Statistics of Bangladesh. Ministry of Planning. Government of the People's Republic of Bangladesh.

Dhindsa, K.S. and Sharma, A. 1997. A regional analysis of growth and supply responses of pulses: A study of Punjab. Indiar Joumal of Agriculural Economics, 52 (1):87-100.

Islam, S., 1991. Soil mutrient status affecting productivity of pulses in the major and potential pulse-growing areas. In: Advances in Pulses Research in Bangladesis. Proc. of the second national workshop on pulses, June 6-8, 1989, BARI, Gazipur. Published by ICRISAT, Patancheru, Andhra Pradesh 502 324, India,

Krishna, R. 1963. Farm supply response in IndiaPakistan: A case study of Punjab region. The Economic Journal, 73 (291): 477-487.

Kurtz, L.T., Boone, L.V., Peck, T.R., Hoeft, R.G., 1984. Crop rotations for efficient nitrogen use, In: Nitrogen in Crop Prodiction, (Ed) Huck, R.D., ASA-CSSA SSSA, Madison, pp 295-317.

Miah, A.A., A. F. M. Maniruzzaman, and M. M. Rahman. 1991. Problems and prospects of pulses production'. In: Advances in Pufses Research in Bangladesh. Proc, of the second national workshop on pulses, June 6-8, 1989, BARI, Gazipur. Published by 
ICRISAT, Patancheru, Andhra Pradesh 502324 , India.

Nerlove, M. 1956. Estimates of the elasticities of supply of selected agricultural commodities. Journal of Farm Economics. 38 (2) 496-503.

Sidhu, J. R. and R. S. Sidhu. 1988. Growth and area response of commercial crops in Punjab: Some policy issues. Indian Journal of Agriculural Economics, 43 (3): $473-480$.

Sud, L. and A. S. Kahlon. 1969. Estimation of acreage response to price of selected crops in Punjab State, Indian Journal of Agriculural Economics, 24 (3): 46-50.

Senanayake, L., Knievel, D.P., Stevena, S. E., 1987. Nodulation and symbiotic nitrogen fixation of cowpea (Vigna unguiculata L.). Plam and Soil 99, 435-439.

Zapata, F., Danso, S.K.A., Hardarson, G., Fried, M. 1987. Nitrogen fixation and translocation in field-grown fababean. Agronomy Journal 79, 505-509. 